\title{
Rates of proteolysis in the rumen of the soluble proteins casein, Fraction I (18S) leaf protein, bovine serum albumin and bovine submaxillary mucoprotein
}

\author{
By J. H. A. NUGENT*, W. T. JONES†, D. J. JORDAN AND J. L. MANGAN \\ Biochemistry Department, ARC Institute of Animal Physiology, Babraham, \\ Cambridge CB2 $4 A T$
}

(Received 21 July 1982-Accepted 12 April 1983)

1. The rate of proteolysis in the rumen was dependent on the soluble protein used. With a sheep on a hay + concentrate diet the rates (approximately $V_{\max }$ ) for casein, Fraction I leaf protein and bovine serum albumin were $16.5,3.4$ and $0.9 \mathrm{mg}$ protein nitrogen $/ 1$ per min respectively.

2. Change of diet from hay + concentrate to fresh lucerne (Medicago sativa) increased the proteolytic rates for all three proteins.

3. Bovine submaxillary mucoprotein degraded extremely slowly in the rumen at approximately $0.5-$ $0.6 \mathrm{mg} \mathrm{N} / 1$ per min and its sialic acid component was degraded at a similar rate to that of the protein chain.

4. Uniformly ${ }^{14} \mathrm{C}$-labelled Fraction I leaf protein was used to demonstrate that in the presence of a second protein, competition for enzymic sites occurred. In Fraction I and bovine serum albumin mixtures, reduced rates for the individual proteins of the mixture were observed compared with the proteins treated separately.

5. Treatment of bovine serum albumin with dithiothreitol $(0.2 \mathrm{~g} / 1)$ to cleave disulphide bridges increased the rates of proteolysis by as much as $8 \cdot 5$-fold.

The extent to which dietary proteins are degraded in the rumen and the proportion which escapes degradation and is subsequently hydrolysed and absorbed in the lower digestive tract is recognized as an important factor in the nutrition of ruminants (Burroughs et al. 1971; Miller et al. 1977; Roy et al. 1977; Black et al. 1981). The dietary and endogenous proteins which are most likely to be fermented rapidly in the rumen are soluble, for example, casein (McDonald \& Hall, 1959; Henderickx \& Martin, 1963). Proteolysis of soluble proteins in the rumen, however, has not been extensively investigated. A recent review (Demeyer \& Van Nevel, 1980) summarizes earlier studies.

In a previous paper (Nugent \& Mangan, 1981) the characteristics of the rumen proteolysis of Fraction I leaf protein, ribulose-1,5-bisphosphate carboxylase (E.C.4 1 1 1 .39), the main soluble protein of plant leaves, was studied in detail. It was shown that proteolysis followed the kinetics of an enzyme-catalyzed reaction giving a Michaelis-Menten curve from which the Michaelis constant $\left(K_{\mathrm{m}}\right)$ and maximum velocity $\left(V_{\max }\right)$ values could be calculated. The characteristics of proteolysis remained remarkably constant over a considerable period of time on a particular diet and this stability made it possible to compare the proteolysis of several proteins and their interactions. Broderick (1978), using different methods, was able to show that the degradation of azo-substituted casein followed first-order kinetics. The earlier work of Mangan (1972) showed that casein and ovalbumin degraded in the bovine rumen at different rates, but no interaction was observed. The present study compared the degradation of casein, Fraction I leaf protein, bovine serum albumin and bovine submaxillary mucoprotein (BSM) individually and in mixtures. A preliminary account of some of the observations has been presented (Mangan et al. 1977; Nugent \& Mangan, 1978).

Present addresses: *The Ciba Foundation, 41 Portland Place, London W1N 4BN. †Applied Biochemistry Division, DSIR, Palmerston North, New Zealand. 


\section{EXPERIMENTAL}

\section{Animals}

Two Clun Forest sheep and three dry Jersey cows, all with permanent rumen cannulas, were maintained under the conditions described by Nugent \& Mangan (1981). The sheep rations were either $2 \mathrm{~kg}$ fresh lucerne (Medicago sativa $\mathrm{L}$., cv. Europe) given at 09.00 and 16.30 hours or $1 \mathrm{~kg}$ chaffed hay $+100 \mathrm{~g}$ crushed oats given once daily at 09.00 hours. The cows were given either $13 \mathrm{~kg}$ fresh lucerne or $1.8 \mathrm{~kg}$ hay $+250 \mathrm{~g}$ crushed oats $+100 \mathrm{~g}$ linseed cake at 09.00 and 16.30 hours.

Experiments in vivo were carried out as described by Mangan \& West (1977) with continuous sampling of rumen fluid by pumping from a probe in the mid-ventral sac. The probe incorporated a stainless steel filter, 32 gauge wire and 30 mesh designed to exclude only coarse fibres. The artificial rumen, volume $400 \mathrm{ml}$, was used as described by Nugent \& Mangan (1981) and was equivalent to approximately one-hundredth the volume of a cow's rumen or one-tenth that of a sheep. Rumen fluid was transferred anaerobically to the artificial rumen without filtering. Protein and CrEDTA marker were added to the artificial rumen in the same proportions as the in vivo experiments. The sampling procedure was similarly correlated and samples taken replaced by an equal volume of synthetic parotid saliva (McDougall, 1948). The circular Warburg apparatus (E. Braun, Melsungen) was used for micro-fermentations, $4-5 \mathrm{ml}$, under the conditions described by Nugent \& Mangan (1981).

\section{Proteins}

Fraction I leaf protein was prepared from lucerne by the method of Jones \& Mangan (1976) and uniformly-labelled with ${ }^{14} \mathrm{C}$ as described by Nugent \& Mangan (1981). Casein was 'light white soluble' (Hopkins and Williams, Chadwell Heath, Essex) and bovine serum albumin was Fraction V (Sigma Chemical Co. Ltd, Poole, Dorset). BSM was prepared from submaxillary glands of freshly-slaughtered cattle by the method of Lyttleton (1964). BSM was stored as the acetyl trimethyl ammonium bromide complex in ethanol ( $800 \mathrm{ml}$ ethanol/1) at $-20^{\circ}$ and before use was dissolved and freed from the complexing agent by dialysis against three changes of synthetic saliva (McDougall, 1948).

\section{Analytical}

Determinations of total $\mathrm{N}$, non-protein- $\mathrm{N}$, soluble protein-N, ammonia-N, peptide-N and $\alpha$-amino-N were carried out by Autoanalyzer methods (Mangan \& West, 1977). BSM was not reliably precipitated by trichloracetic acid and the method of Jones \& Mangan (1977) using the condensed tannin of sainfoin (Onobrychis viciifolia) at $0^{\circ}$ was applied. ${ }^{14} \mathrm{C}$ radioactivity measurements were made as described by Nugent \& Mangan (1981). CrEDTA was measured by atomic absorption spectrometry using a Pye Unicam SP 191 at a wavelength of $358 \mathrm{~nm}$. Polyacrylamide gel electrophoresis was carried out using the apparatus of Reid \& Bieleski (1968) under conditions described by Nugent \& Mangan (1981). Sialic acid was measured by the method of Svennerholm (1957).

\section{RESULTS}

Individual rates of proteolysis of casein, bovine serum albumin, Fraction $I$ leaf protein and $B S M$

In a sheep maintained on the hay + concentrate ration, known quantities of each protein together with a known amount of CrEDTA marker were added in solution to the rumen in three separate experiments, $5 \mathrm{~h}$ after feeding. At this time rapid fermentation of dietary components had ceased and soluble protein in the rumen was at a low stable level. Rumen volumes were calculated from $\mathrm{Cr}$ concentrations extrapolated to zero time by a dilution 


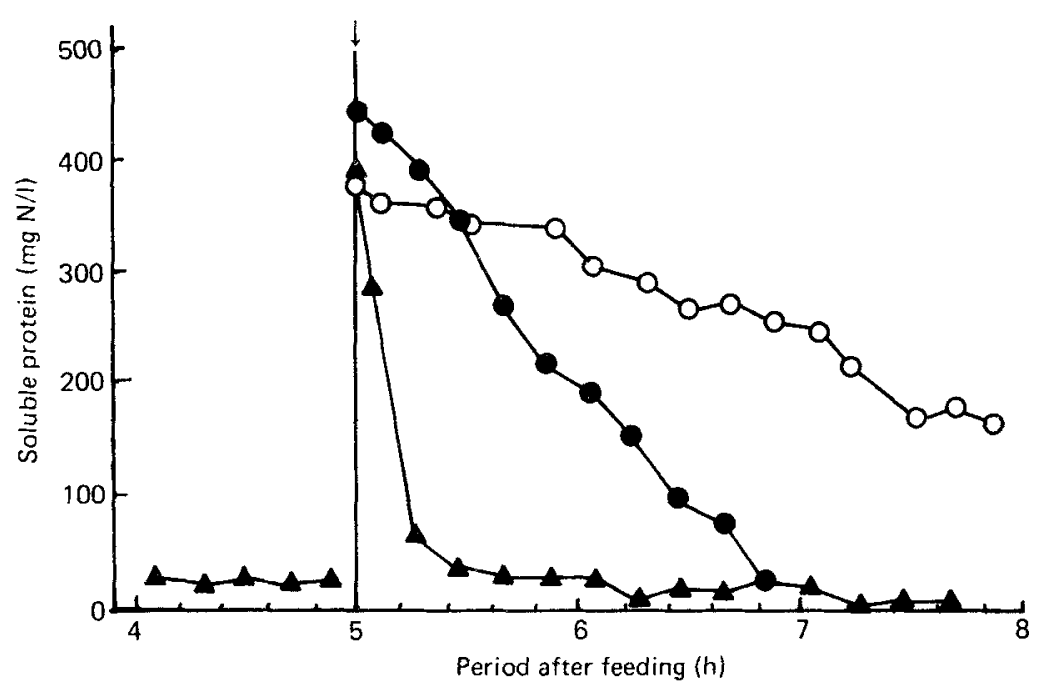

Fig. 1. Degradation of casein (A), Fraction $I$ leaf protein $(O)$ and bovine serum albumin $(O)$ in the rumen of a sheep fed on a hay + concentrate ration. The proteins in solution were added together with CrEDTA marker $(\downarrow)$ in three separate experiments under identical conditions.

equation (Hyden, 1956). Complete mixing of the administered protein in the rumen fluid required an appreciable time and the initial concentration of soluble proteins was calculated from the rumen volume and known amounts of protein administered. Subsequent concentrations were measured experimentally and corrected for dilution. Fig. 1 shows that the rates of proteolysis for three proteins added individually were different, casein being degraded rapidly, bovine serum albumin very slowly and Fraction I protein at an intermediate rate. The exact rates are given in Table 1, Expt 1a-c, and show that Fraction I was degraded approximately four times faster than bovine serum albumin and approximately five times slower than casein.

When the diet of the sheep was changed to fresh lucerne which has a higher content of soluble protein, new rates of proteolysis were established as shown in Fig. 2 and Table 1, Expt $1 \mathrm{~d}-\mathrm{f}$. The casein rate remained very high and bovine serum albumin was hydrolysed considerably faster than in Expt $1 \mathrm{~b}$. Fraction I protein was degraded very rapidly, almost as fast as casein. From the values in Table 1, the rate increase for bovine serum albumin was approximately three-fold. The new rates for Fraction I and casein were too rapid to be measured accurately but the rate for Fraction I was increased by a factor of approximately nine-fold. Results for simultaneous incubations in the artificial rumen of Expt $1 \mathrm{a}-\mathrm{c}$, i.e. Expt $1 \mathrm{~g}-\mathrm{i}$ in Table 1, confirm the large differences in rates for the three proteins. Values for five replicated experiments with approximately the same initial protein concentration, each with duplicate incubations in the Warburg apparatus, are given in Table 1, Expt 2a and $b$ for Fraction I protein and casein respectively. Rumen fluid from one sheep on the hay + concentrate diet was used. The rates are similar to the values obtained in vivo and confirm the different rates for the two proteins. The small standard error indicates good reproducibility. Cattle experiments with Fraction I protein were limited by the supply of Fraction I but Expt 3 shows that the rates of rumen proteolysis were lower than in sheep and that the rate for casein was two to three times that for Fraction I. With casein, Expt 4, a high rate of proteolysis was also observed on the hay + concentrate diet.

The degradation of BSM was considered separately because of its unusual structure (Gottschalk, 1960) in which about $45 \%$ of the BSM consists of approximately equal 


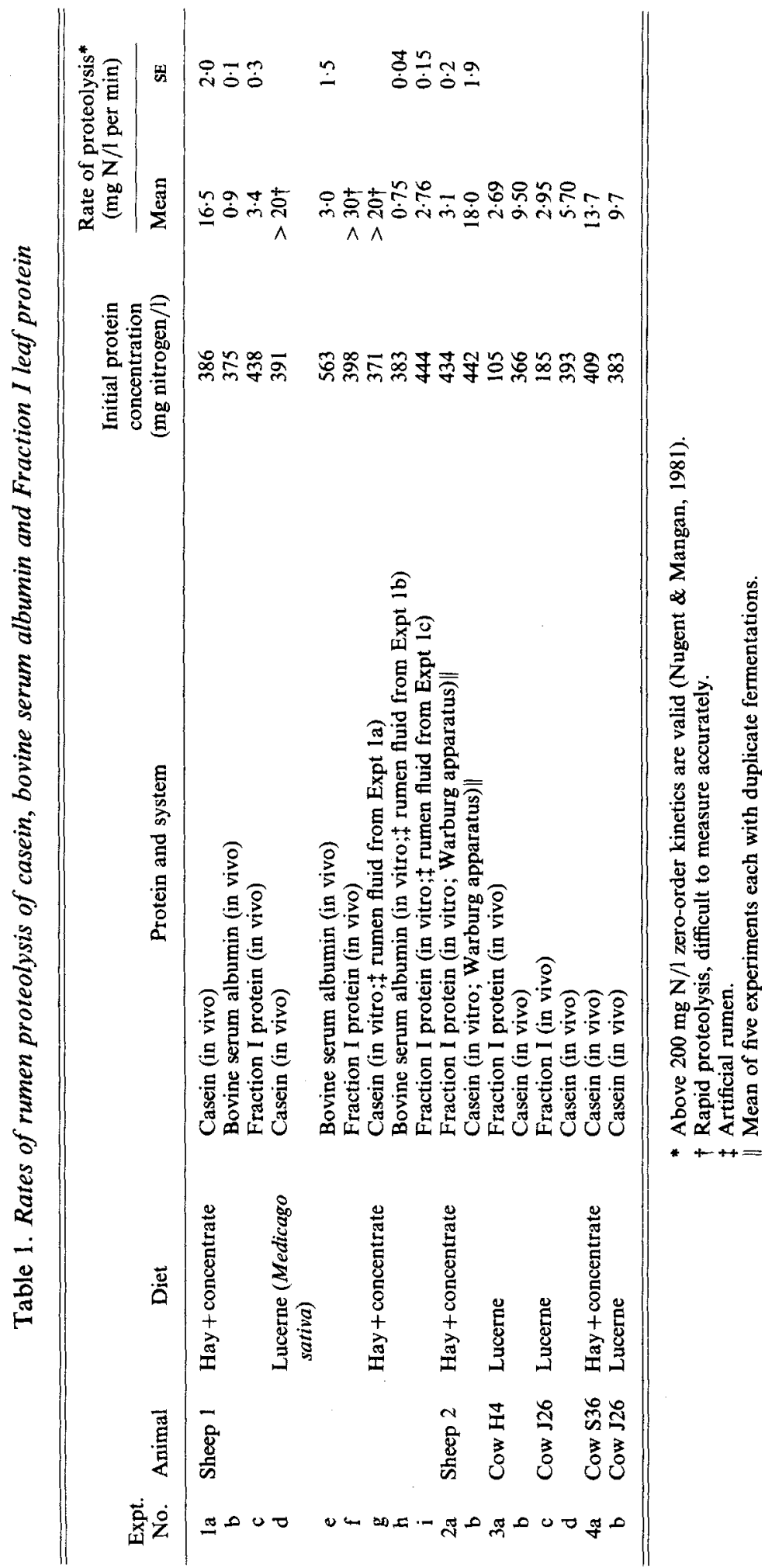




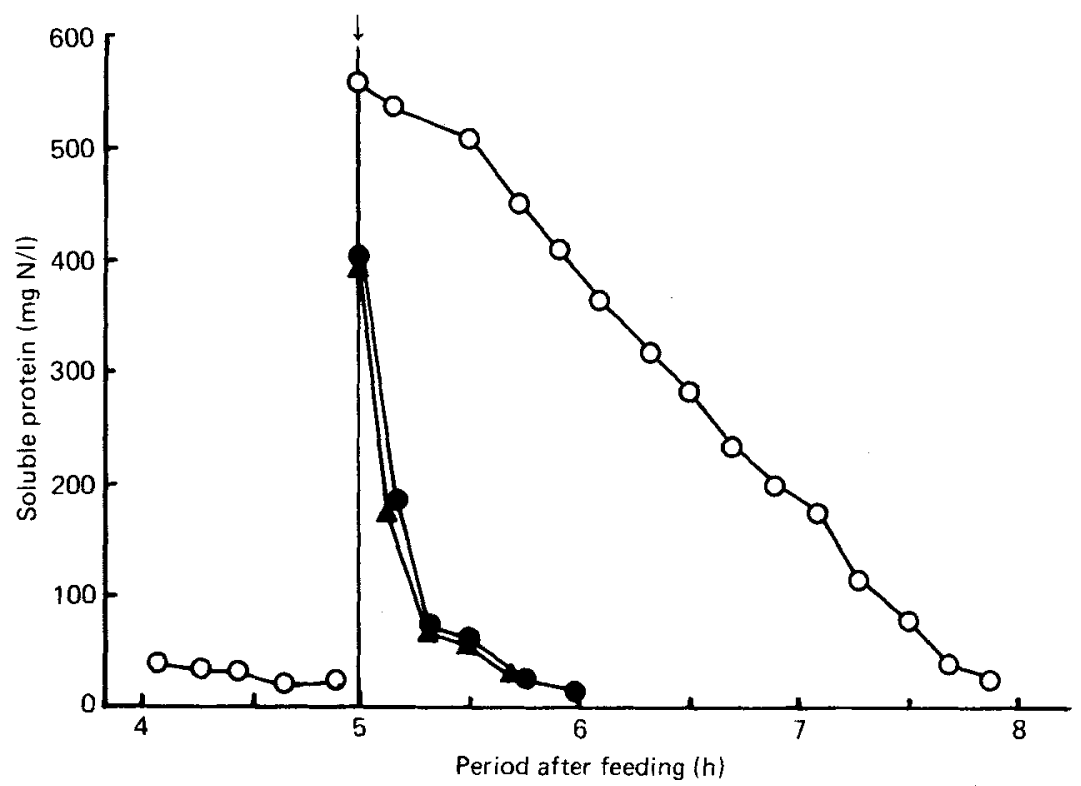

Fig. 2. Degradation of casein (A), Fraction I leaf protein (O) and bovine serum albumin $(O)$ in the rumen of a sheep fed on fresh lucerne (Medicago sativa L.) under the same conditions as in Fig. 1.

amounts of $N$-acetyl galactosamine and sialic acid as side chains on the protein structure. Table 2 shows the results obtained with two cows and one artificial rumen. The rate of proteolysis was very low, in all cases less than that of bovine serum albumin shown in Table 1, indicating that the protein component of BSM was extremely resistant to proteolysis. The rate of sialic acid degradation as $\mathrm{mg} / \mathrm{l}$ per min was expressed relative to the rate of proteolysis (rate of sialic acid degradation: rate of proteolysis) and compared with the ratio, sialic acid content: protein-N of BSM calculated from the data of Gottschalk (1960). The values for the in vivo experiments were close to $100 \%$ which indicates that the sialic acid was degraded at a rate linked closely to the rate of proteolysis of the protein chain of the molecule.

\section{Interaction between Fraction I protein and bovine serum albumin}

The fact that proteolysis in the rumen showed characteristics of an enzyme-catalyzed reaction (Nugent \& Mangan, 1981) and that different proteins had widely different rates of proteolysis indicated the possibility of competitive inhibition occurring between proteins. Fig. 3 demonstrates that as found by Nugent \& Mangan (1981), proteolysis of Fraction I protein can be treated as a first-order reaction at low initial protein concentrations. Fig. 3 shows the proteolysis of ${ }^{14} \mathrm{C}$-labelled Fraction I protein in the artificial rumen using rumen fluid from a cow fed on the hay + concentrate diet. The initial concentration of $275 \mathrm{mg} \mathrm{N} / 1$, specific radioactivity $68 \times 10^{3}$ disintegrations/min per $\mathrm{mg} \mathrm{N}$, gave a rate-constant $k$ of 1.02 (SE 0.04) $\times 10^{-2}$ throughout the incubation and an initial velocity of 2.57 (SE 0.14$) \mathrm{mg} \mathrm{N} / 1$ per min. The plot of $\log a / a-x$ where $a$ is the initial concentration and $x$ is the protein hydrolysed, gave the linear first-order relationship with a linear correlation of 0.99 .

The experiment was repeated except that bovine serum albumin $(180 \mathrm{mg} \mathrm{N} / \mathrm{l})$ was added after 32 min of incubation. The plot of ${ }^{14} \mathrm{C}$-labelled Fraction I shows that after a time-lag, a new slower rate was established, demonstrating the competition between the two proteins 


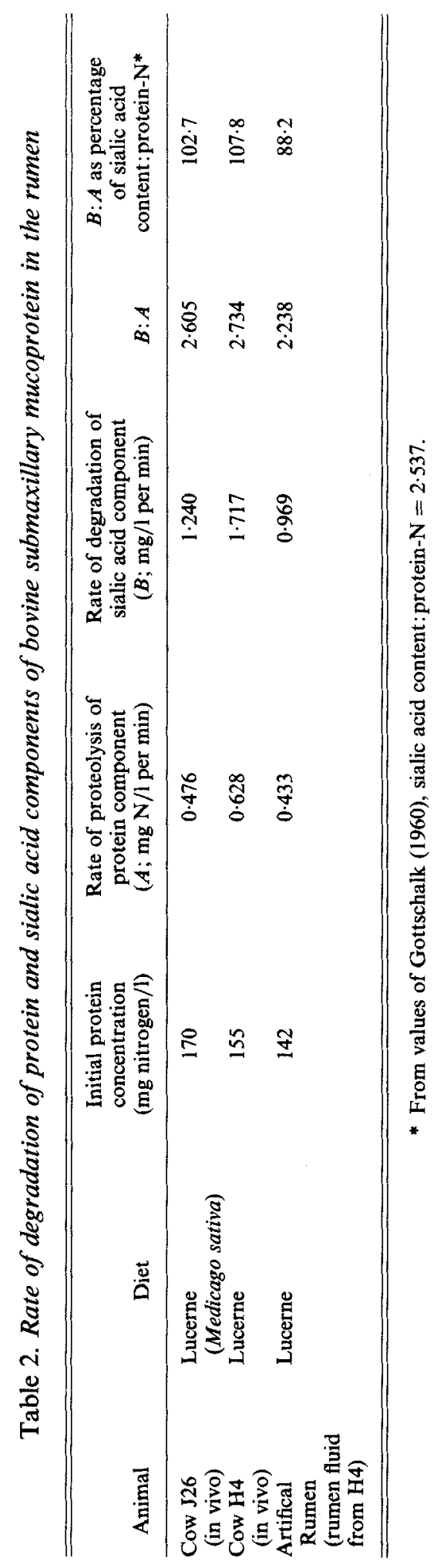




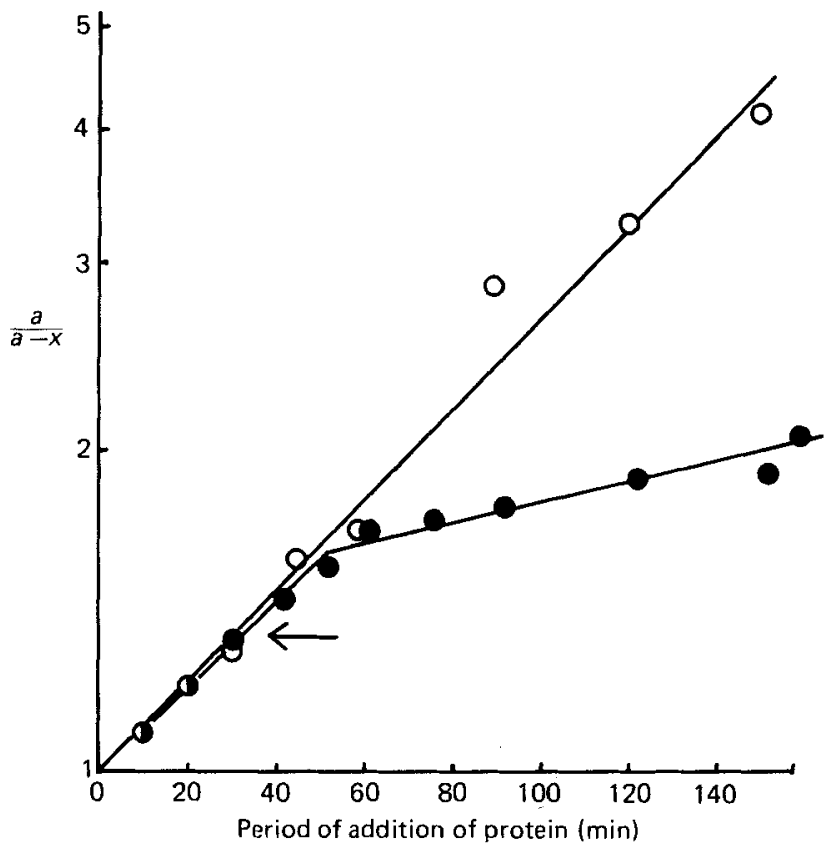

Fig. 3. Proteolysis of ${ }^{14} \mathrm{C}$ Fraction I protein (275 mg nitrogen/l; specific radioactivity $68 \times 10^{3}$ disintegrations/min per mg nitrogen) in vitro (artificial rumen) showing first-order kinetics $(O)$. Bovine serum albumin $(180 \mathrm{mg}$ nitrogen $/ 1)$ was added $(\downarrow)$ in a duplicate experiment $(O)$ with the same amount of ${ }^{14} \mathrm{C}$-labelled Fraction I protein. $a=$ initial concentration of ${ }^{14} \mathrm{C}$ Fraction $\mathrm{I} ; x=$ amount of ${ }^{14} \mathrm{C}$ Fraction I degraded.

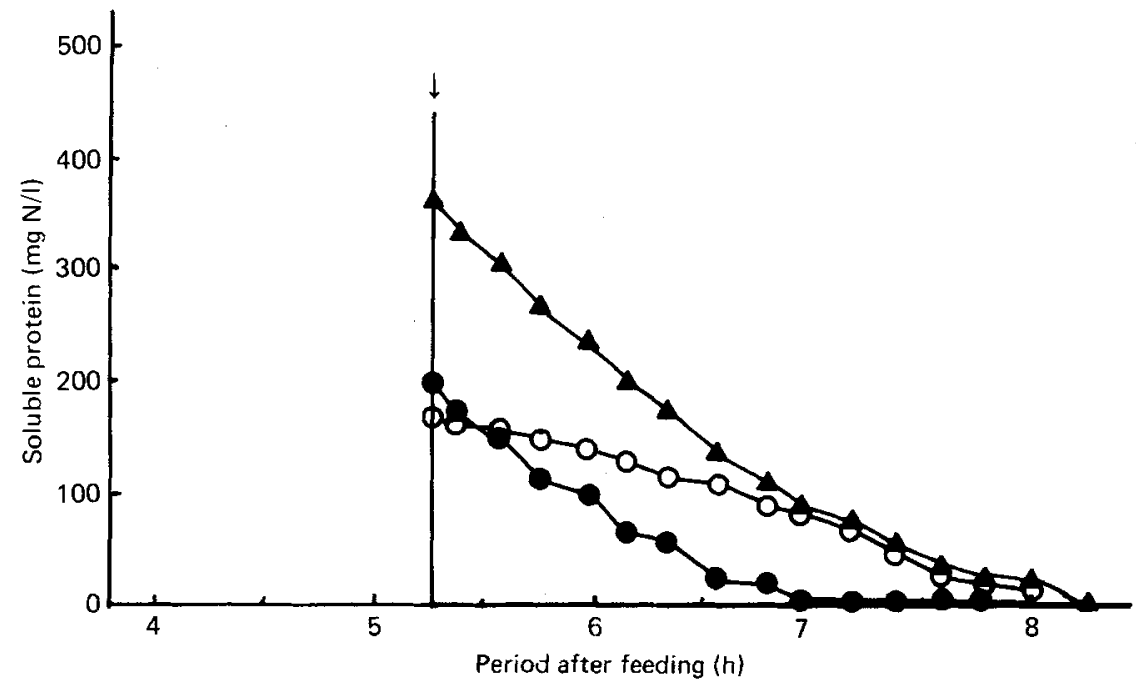

Fig. 4. Degradation of a mixture of Fraction I leaf protein ( $202 \mathrm{mg}$ nitrogen/l) and bovine serum albumin $(166 \mathrm{mg}$ nitrogen/l) in the rumen of a sheep. Total soluble protein $(\mathbf{A})$ (by $\mathbf{K j e l d a h l}$ ), bovine serum albumin $(O)$ and Fraction I protein $(O)$ (by polyacrylamide gel electrophoresis and quantitative staining with Amido black). $\downarrow$, Protein added. 


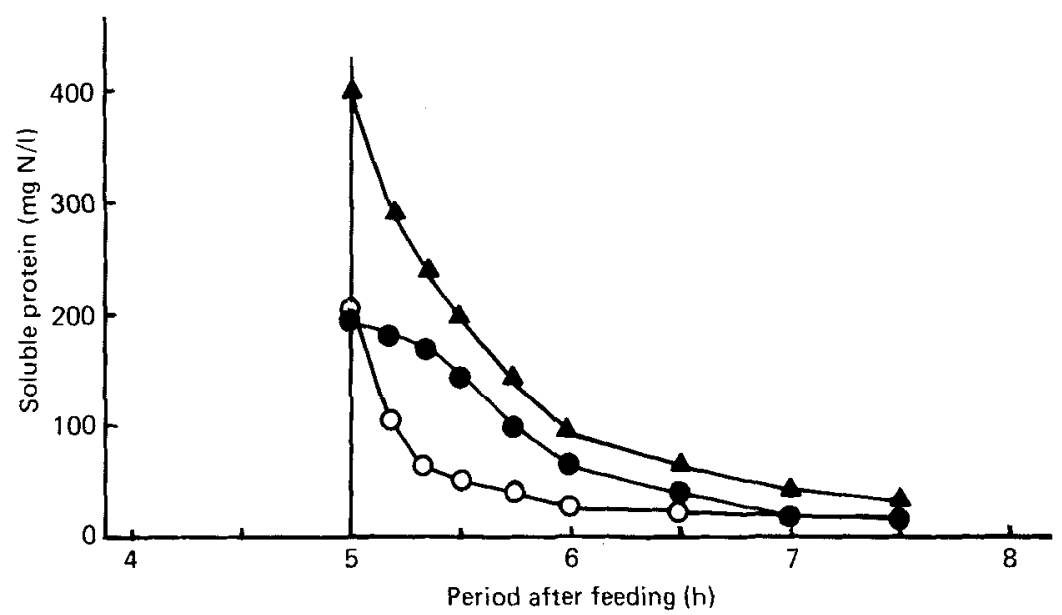

Fig. 5. Proteolysis of a mixture of casein $\left(200 \mathrm{mg}\right.$ nitrogen/l) and ${ }^{14} \mathrm{C}$-labelled Fraction I protein (195 $\mathrm{mg} \mathrm{N} / 1$; specific activity $2.409 \times 10^{3}$ disintegrations/min per $\mathrm{mg} \mathrm{N}$ ) in the artificial rumen, with rumen fluid from a sheep fed on a hay + concentrate diet. Total soluble protein (A) (by Kjeldahl), Fraction $\mathrm{I}(\mathrm{O})\left(\mathrm{N}\right.$ determined by calculation from ${ }^{14} \mathrm{C}$ and initial specific radioactivity) and casein $(\mathrm{O})$ by difference.

for enzymic sites. The time-lag probably reflected the time required before the new mixture of proteins in solution was reflected in the occupation of enzymic sites.

The interaction between Fraction I protein and bovine serum albumin during proteolysis was also studied in vivo in a sheep where the soluble proteins were analysed by quantitative polyacrylamide gel electrophoresis using amido black staining, which is linear up to $300 \mathrm{mg} \mathrm{N} / 1$ for Fraction I. The results are presented in Plate 1 showing the stained gel, and Fig. 4 which gives the plots of total protein and the individual proteins calculated from calibration curves for each protein. The rate of breakdown of total soluble protein fell between the values for the two proteins determined separately as shown in Fig. 1 where there was a similar initial concentration of protein.

The rate of proteolysis of each protein was lower than the rate expected from the initial individual concentration. The effect was greater and more easily noted with Fraction I due to its higher rate of proteolysis. Both proteins were hydrolysed in a similar time course which was equivalent to that seen in incubations with twice the initial amount of these proteins added individually (Fig. 1). This indicates that the rates of proteolysis of both proteins were dependent on the total protein concentration. The result was a lower rate of proteolysis for Fraction I due to the maintenance of high protein levels with the occupation of enzyme sites by bovine serum albumin and vice versa.

\section{The interaction between casein and Fraction I protein}

The proteolysis of a mixture of Fraction I protein (195 mg N/l) and casein ( $200 \mathrm{mg} \mathrm{N} / \mathrm{l})$ in the artificial rumen with rumen fluid from a sheep on a hay + concentrate diet is shown in Fig. 5. The Fraction I was labelled with ${ }^{14} \mathrm{C}$ to a specific radioactivity of 2.41 (SE 0.03$) \times 10^{3}$ disintegrations/min per $\mathrm{mg} \mathrm{N}$ and the concentration of Fraction $\mathrm{I}$ in the rumen fluid was calculated using this factor. Casein was measured as the difference between total soluble protein and Fraction I protein measured by ${ }^{14} \mathrm{C}$ radioactivity. Compared with the two proteins individually the rate of proteolysis of the total protein in the mixture (Fig. 5) fell between the rates for the individuals. The rate of proteolysis of both proteins in the mixture was slowed down by competition between them for proteolytic sites. 
Table 3. The effect on rate of proteolysis ( $\mathrm{mg}$ nitrogen/l per min) by treating bovine serum albumin and Fraction I protein with dithiothreitol $(0 \cdot 2 \mathrm{~g} / \mathrm{l})$ at room temperature for $30 \mathrm{~min}$; in vitro (Warburg) incubations with rumen fluid from a cow (J26) on two diets

(Mean values with their standard errors)

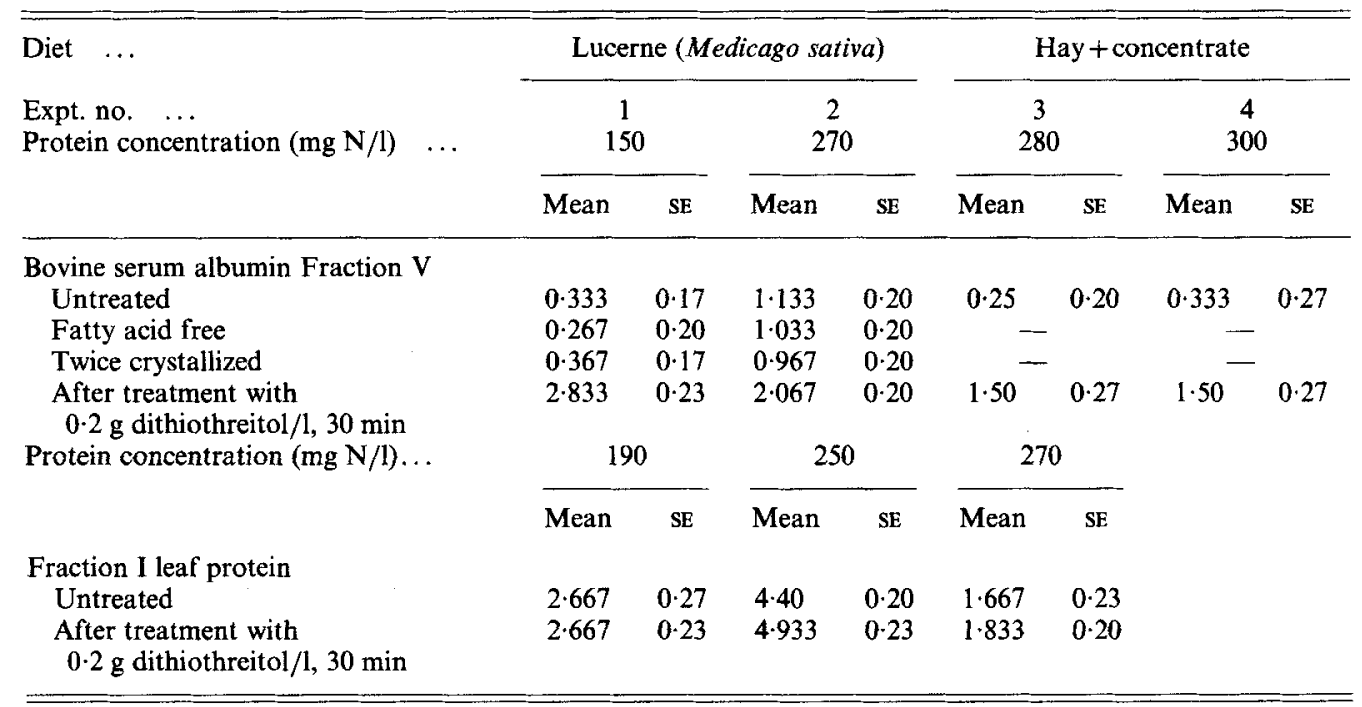

The structure of bovine serum albumin in relation to its rate of proteolysis

The slow rate of proteolysis of bovine serum albumin was investigated further in order to establish the reason for its behaviour. The bovine serum albumin generally used was Fraction $\mathrm{V}$ and because of its high affinity for lipid absorption, bovine serum albumin was prepared free from lipid by the method of Chen (1967). As shown in Table 3 the rate of proteoloysis was not increased by this purification. Twice crystallized bovine serum albumin also gave the same slow rate of proteolysis. The absence of impurities acting as inhibitors suggested that the tightly folded globular nature of this protein cross-linked with disulphide bridges was the cause of its resistance to proteolysis. Treatment of bovine serum albumin with dithiothreitol (aqueous $0.2 \mathrm{~g} / \mathrm{l}$ solution) at room temperature for $30 \mathrm{~min}$ before proteolysis with rumen fluid, in order to break disulphide bridges, resulted in a very large increase in the rate of proteolysis. Four experiments in Table 3 showed increases of approximately two to eight times the normal rate.

Fraction I protein, which contains no disulphide bridges, showed no increases in proteolytic rates when treated with dithiothreitol in the same way and using rumen fluid from a cow on both lucerne and hay + concentrate rations.

\section{DISCUSSION}

The present studies on four soluble proteins, casein, Fraction I leaf protein, bovine serum albumin and BSM have shown that the rates of proteolysis in the rumen are markedly different and are dependent on factors in addition to solubility. Probably the most important is the structural folding of the protein molecule and in the case of serum albumin breaking the disulphide bridges with dithiothreitol to open out the molecule converted it from a protein highly resistant to proteolysis to one which was readily degraded in the rumen. This suggests that relatively mild cross-linking may be effective in reducing hydrolysis in the rumen and vigorous treatments to make soluble proteins insoluble in rumen fluid may not be necessary in order to inhibit proteolysis in the rumen. Mahadevan et al. (1980), in studies 
on the degradation of soluble proteins by the protease from the rumen organism Bacteroides amylophilus, also observed that serum albumin was degraded slowly but that treatment with performic acid or $\beta$-mercaptoethanol accelerated its rate of proteolysis. Nugent \& Mangan (1981) showed that mild formaldehyde treatment of Fraction I protein, insufficient to make it insoluble, reduced the absorption of the protein by rumen bacterial cells and presumably would inhibit proteolysis. The known structural differences between bovine serum albumin, a tightly-folded protein held together with numerous disulphide bridges and Fraction $I$, a linear protein with no known disulphide bonds and consisting of subunits held together mainly by hydrogen bonding, is probably sufficient to explain the differences between the proteolytic rates. The extremely rapid rate for casein is not easy to explain, but it has unusual properties such as its high content of phosphoserine which may increase its affinity for the enzyme sites, together with an absence of disulphide bonds.

The demonstration that soluble proteins react with rumen fluid with the kinetics of a normal enzyme-catalyzed system has made it possible to consider proteolysis in the rumen quantitatively and to show that competitive inhibition can occur. The observation that the presence of a slowly-metabolized protein such as bovine serum albumin can significantly affect the proteolysis of Fraction I protein by simple competition could be of importance in the control of proteolytic activity in a herbage-fed animal. In a previous paper (Nugent \& Mangan, 1981), where the characteristics of proteolysis of Fraction I was studied in detail, it was shown that the high rate of proteolysis of Fraction I was greatly increased when the animal was given lucerne and in those circumstances, which would be the normal ones, there was little chance of Fraction I escaping the rumen undegraded. The amino acid composition of Fraction $I$ is such that it has a high nutritional value (Ershoff et al. 1978) and the nutritional advantage in preventing proteolysis in the rumen by suitable alteration of the protein configuration or by a suitable competitive inhibitor would be considerable. Ørskov et al. (1980) have used whole blood dried at $100^{\circ}$ on to soya bean and groundnut meal as a protection against rumen degradation. Although the serum albumin is probably heat denatured by this treatment, there is a possibility that some may remain soluble and protect against rumen degradation by competitive inhibition of proteolysis.

Sufficient information is not yet available to obtain a broad view of the susceptibility of different dietary proteins in ruminant feeds to proteolysis in the rumen, but there seems no doubt that there is a wide range. Casein has an abnormally-high rate of proteolysis with cattle and sheep fed on a variety of rations. Fraction I, probably the most important and widely-occurring protein in all green feedstuffs, and derivatives such as dried grass and silage, has an intermediate rate which is to a considerable extent affected by the animal's diet. Two highly-resistant, but quite soluble proteins are serum albumin and ovalbumin. The former is available in relatively large amounts as a meat by-product and may be a useful source of a protein which could be used to restrict the wasteful proteolysis of more-readily-degraded proteins. The role of BSM is of particular interest. Its very slow rate of proteolysis may allow an appreciable quantity to escape degradation in the rumen and after digestion and absorption from the small intestine could represent an efficient system for recycling endogenous protein. BSM is also implicated as a causative factor in the disorder of bloat in cattle. The primary foaming agent is probably Fraction I leaf protein but submaxillary mucoprotein is known (Jones et al. 1978) to increase foam persistence in rumen fluid. It is also probable that BSM would behave like bovine serum albumin and slow the proteolysis of Fraction I protein.

Further basic studies, probably with isolated rumen proteolytic bacteria such as Bacteroides R8/4 (Hazlewood \& Nugent, 1978) should provide information on a wider range of soluble proteins. This organism has recently been used (Hazlewood \& Edwards, i981) to demonstrate partial inhibition of proteolytic function by peptide inhibitors. 
The authors wish to thank Dr F. A. Harrison for rumen fistulation of the animals and $\mathrm{Mr}$ D. W. Grime for growing ${ }^{14}$ C-labelled lucerne in a growth chamber. J.H.A.N. wishes to thank the Meat \& Livestock Commission for a Postgraduate Fellowship, W.T.J. the New Zealand Government for a DSIR Fellowship and Dr B. A. Cross, Director of the Institute, for permission to carry out the research.

\section{REFERENCES}

Black, J. L., Beever, D. E., Faichney, G J., Howarth, B. R. \& Graham, N. McC. (1981). Agricultural Systems 6, 195-220.

Broderick, G. A. (1978). Journal of Nutrition 108, 181-190.

Burroughs, W., Trenkle, A. \& Vetter, R. L. (1971). Veterinary Medicine and Small Animal Clinician 66, 238-247.

Chen, R. F. (1967). Journal of Biological Chemistry 242, 173-181.

Demeyer, D. I. \& Van Nevel, C. J. (1980). Proceedings of the Nutrition Society 39, 89-95.

Ershoff, B. H., Wildman, S. G. \& Kwanyuan, P. (1978). Proceedings of the Society of Experimental Biology and Medicine 157, 623-630.

Gottschalk, W. (1960). Nature 186, 949-951.

Hazlewood, G. P. \& Edwards, R. (1981). Journal of General Microbiology 125, 11-15.

Hazlewood, G. P. \& Nugent, J. H. A. (1978). Journal of General Microbiology 106, 369-371.

Henderickx, H. \& Martin, J. (1963). Compte Rendu de Recherches, IRSIA, Brussels 31, 11-66.

Hyden, S. (1956). Kungliga Lantbruckshogskolans Annalen 22, $139-145$.

Jones, W. T., Lyttleton, J. W. \& Mangan, J. L. (1978). New Zealand Journal of Agricultural Research 21, 401-407.

Jones, W. T. \& Mangan, J. L. (1976). Journal of Agricultural Science, Cambridge 86, 495-501.

Jones, W. T. \& Mangan, J. L. (1977). Journal of the Science of Food and Agriculture 28, 126-136.

Lyttleton, J. W. (1964). New Zealand Journal of Agricultural Research 7, 228-237.

McDonald, I. W. \& Hall, R. J. (1959). Biochemical Journal 67, 400-405.

McDougall, E. I. (1948). Biochemical Journal 43, 99-109.

Mahadevan, S., Erfle, J. D. \& Sauer, F. D. (1980). Journal of Animal Science 50, 723-728.

Mangan, J. L. (1972). British Journal of Nutrition 27, 261-283.

Mangan, J. L., Jones, W. T., Nugent, J. H. A. \& Jordan D. J. (1977). Proceedings of the 11th Federation of European Biochemical Societies Meeting, Copenhagen A 3-2, 903.

Mangan, J. L. \& West, J. (1977). Journal of Agricultural Science, Cambridge 89, 3-15.

Miller, E. R., Balch, C. C., Ørskov, E. R., Roy, J. H. B. \& Smith, R. H. (1977). Proceedings 2nd International Symposium on Protein Metabolism and Nutrition, p. 137. Wagenigen: Pudoc.

Nugent, J. H. A. \& Mangan, J. L. (1978). Proceedings of the Nutrition Society 37, 48A.

Nugent, J. H. A. \& Mangan, J. L. (1981). British Journal of Nutrition 46, 39-58.

Ørskov, E. R., Mills, C. F. \& Robinson, J. J. (1980). Proceedings of the Nutrition Society 39, 60A.

Reid, M. S. \& Beileski, R. L. (1968). Analytical Biochemistry 22, 374-381.

Roy, J. B. H., Balch, C. C., Miller, E. L., Ørskov, E. R. \& Smith, R. H. (1977). Proceedings 2nd International Symposium on Protein Metabolism and Nutrition, p. 126. Wagenigen: Pudoc.

Svennerholm, L. (1957). Biochimica et Biophysica Acta 24, 604-611. 
Plate 1. Polyacrylamide gel electrophoresis of samples of rumen fluid from a sheep with a mixture of Fraction I leaf protein (202 mg nitrogen/1) and bovine serum albumin (166 mg nitrogen/l) administered by rumen fistula. (a) Origin, (b) Fraction I protein, (c) bovine serum albumin dimer, (d) bovine serum albumin. Sample 1, original protein mixture; samples $2-10$, rumen fluid samples $30,42,54,66,78,90,102,126$ and 150 min after addition of protein mixture. Amido black staining. 
British Journal of Nutrition, Vol. 50, No. 2.

Plate 1

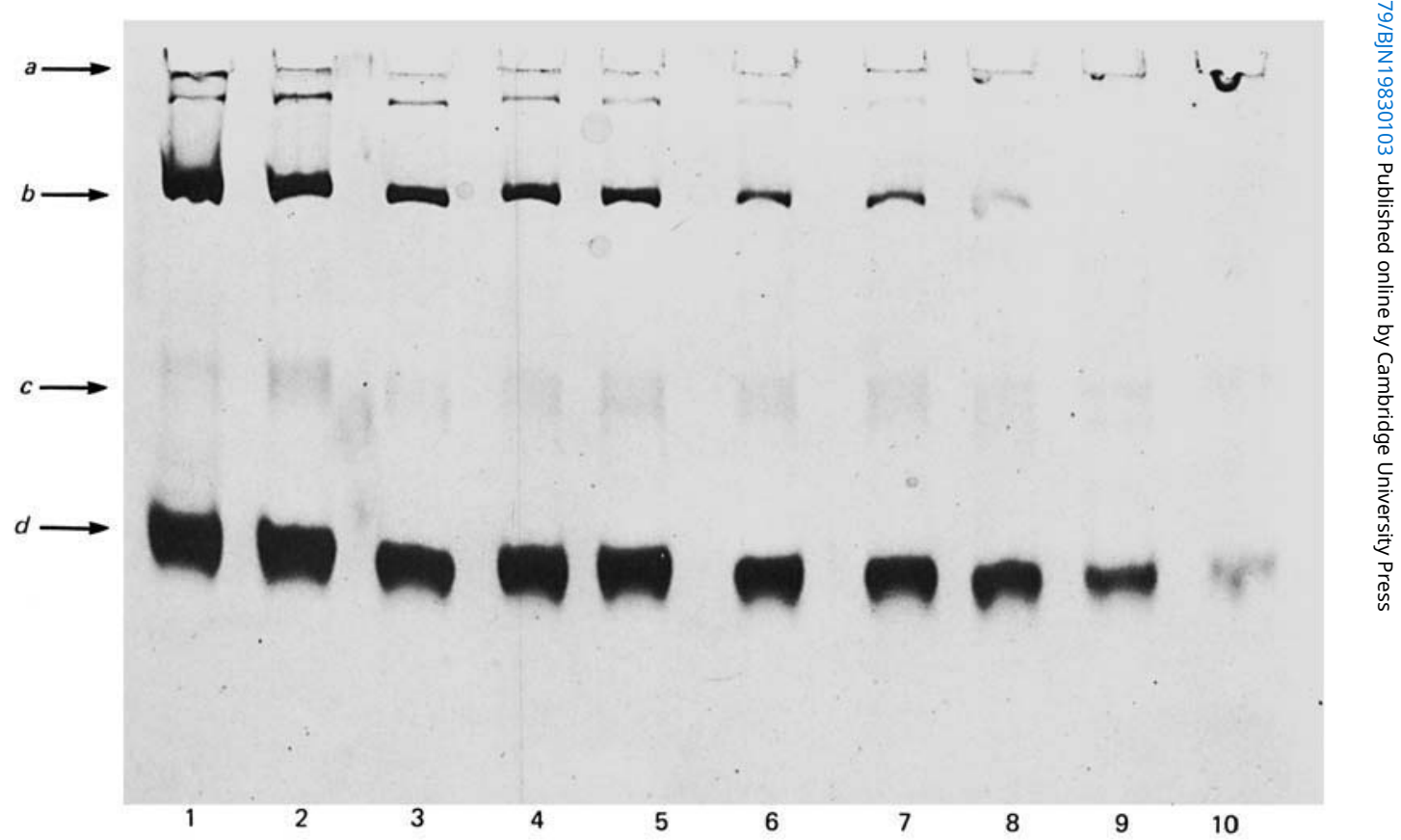

